\title{
Ironie a parodie jako zdroj významů v Nabokovově románu Bledý oheň
}

\author{
Zdeněk Pechal (Olomouc)
}

\begin{abstract}
Abstrakt
Román Bledý oheň se skládá ze čtyř částí. Za textový základ Ize považovat poému Bledý oheň, jež je uvedena předmluvou vydavatele, za básní následuje kritický komentář s poznámkami, které několikrát převyšuji rozsah poémy, román je uzavřen věcným rejstřikem. Nezpochybnitelným autorem všech čtyř částí je Vladimir Nabokov. Evidentní rozpor mezi textem básně a jeho údajně kritickým komentářem je hlavním strukturním problémem románu. Dalším zdrojem napětí je rozdvojení umělecké reality mezi pưvodní obraz či světelný zdroj a jejich pouhý odraz a stín. Mnohotvářný nespolehlivý vypravěč (jehož subjektivní verze může události zkreslovat, maskovat a zatajovat) dotvárí dvojitý významový základ románu. Vzájemně protichůdné vypravěčské masky jsou zdrojem ironie a parodie a tím je textová nejednoznačnost dále násobena a obohacována. Výsledkem je nejen nejednoznačnost, ale i aktivace širokého významového prostoru mezi „ano“ a „ne“. Výsledkem románové významové ambivalence je pak současná platnost „ano“ i „ne“. Podvojná estetika románu vyvolává představu, že za primárním textem je další text, který čtenář musí hledat a „prečíst“ jiným způsobem než originální text.
\end{abstract}

\section{Klíčová slova}

Vladimir Nabokov; román Bledý oheň; vypravěč; kritický komentár; parodie; ironie; významová ambivalence; současná platnost „ano“ i „ne“

\begin{abstract}
Irony and Parody as a Source of Meanings in Nabokov's Novel Pale Fire

The novel Pale Fire consists of four part and the poem Pale Fire - preceded by a publisher's preface - can be considered the original textual basis. The poem itself is followed by a critical commentary with notes several times larger than the poem itself, and at the end of the index. Undisputed author of all four parts is Vladimir Nabokov. A distinct contradiction between the text of the poem and its allegedly critical commentary is the main structural problem of the novel. Another source of the tension is the bifurcation of artistic reality between the original image or source of light against the mere reflection and shadow. The narrative of the multifaceted unreliable narrator (whose subjective version of events can distort, mask and hide information) creates a double basis for the novel. The opposing narrative masks are the source of novel's irony and parody, thus the text ambiguity further multiplied and significantly enriched. The result is not only ambiguity, but a wide space between "yes" and "no" is filled. The result of novel's ambivalence is the current validity of "yes" and "no". Double aesthetics of the novel raises the idea that behind the primary text there is another text that the reader must look for and "read" in another way than the original text.
\end{abstract}

\section{Key words}

Vladimir Nabokov; novel Pale Fire; narrator; the critical commentary; parody; irony; ambivalence; simultaneously "yes" and „no" 
Román Bledý oheñ (Pale Fire) vydal Vladimir Nabokov v r. 1962. Román má složitou strukturu, o níž se vedou mezi odborníky spory. ${ }^{1}$ Je ovšem nezpochybnitelné, že se román skládá ze čtyř částí: výchozím textem románu je poéma Bledý oheň, která sestává z 999 veršů. Této poémě předchází editorská předmluva a následuje velmi obsáhlý kritický komentář s poznámkovým aparátem, který několikanásobně převyšuje komentovanou poému. Román je zakončen jmenným rejstříkem. Všechny tyto čtyři části byly napsány Vladimirem Nabokovem a on je jejich nezpochybnitelným fyzickým autorem. Vladimir Nabokov o takto členěné románové realitě (čtyři části) vypráví prostřednictvím jednající postavy a zároveň vypravěče Charlese Kinbotea. Charles Kinbote je jediným zdrojem, který informuje čtenáře o Johnu Shadeovi jako o autorovi poémy Bledý oheñ. ${ }^{2}$ Editorská předmluva je podepsána Charlesem Kinbotem, stejně tak je autorizován komentár k poémě a jeho jmenný index. Prostřednictvím editorské předmluvy vypravěče Kinbotea je vytvářena u čtenáře představa, že byl přítelem a sousedem Johna Shadea, že Kinbote byl u zrodu básnického textu, a dokonce se podílel na jeho spoluvytváření. Z jediného zdroje informací o románové realitě, tj. opět od Charlese Kinbotea, je zřejmé, že k textu poémy byl vytvořen komentář, který má vytvářet u čtenáře představu vědeckého a kritického aparátu. Komentář má vzbudit dojem, že věcně doplňuje výchozí text poémy o výkladové poznámky, které jsou nezbytné pro celkové pochopení kontextu editovaného díla.

\section{Předmluva editora}

Pokud se podíváme na editorskou předmluvu, je jasné, že nemáme před sebou věcný sumář bibliografických dat ani strohý výčet editorských poznámek a není to ani výčet nutných faktografických východisek k textu poémy, které by měly ospravedlnit ten či onen editorský postup a vysvětlit nezbytné textologické souvislosti. Jde spíš o needitorský vstupní text, který se pokouší ospravedlnit roli editora Charlese Kinbotea a nachází podivná ospravedlnění, proč je právě on povolán redigovat text poémy Johna Shadea a proč právě on musí tento text připravit pro vydání. Sdělení Johna Kinbotea nabývají místy zcela nepatřičného osobního tónu, kterému nechybí sebechvála, impertinence, výpady proti konkurentům, kteří by údajně chtěli zasahovat do jeho výlučných práv v editování textu Johna Shadea. Jde o editorskou předmluvu plnou nejrůznějších narážek místy až pokleslé povahy, které se do detailních podrobností zabývají pletichařením v zákulisí

1 V tomto smyslu v ruském souborném vydání Nabokovova díla poznamenávají A. Luxemburg a S. Iljin: „В «Бледном пламенщ» предельно затемнена проблема авторства всех составляюших произведение текстов, а также реальности (или нереальности) основных его персонажей - Шейда, Кинбота и Градуса." (LJUKSEMBURG, Aleksandr - IL'JIN, Sergej: Kommentarii. Blednoje plamja. In: NABOKOV, Vladimir: Sobranije sočinenij amerikanskogo perioda v pjati tomach. T. 3. Sankt-Peterbur: Simpozium, 1997, s. 655)

2 V tomto smyslu se vyjadřuje o výlučném postavení Charlese Kinbotea jako jediném zdroji informací o románové realitě a zdánlivém autorství některých kompozičních částí rovněž i Vladimir. Aleksandrov: „Основной источник тут, разумеется, Кинбот - мнимьй автор «Предисловия», комментариев и указате ля. “ (ALEKSANDROV, Vladimir: Nabokov i potustoronnost'. Sankt Peterburg: Aletejja, 1999, s. 225) 
akademického života. Vyjadřování Charlese Kinbotea je nasyceno přemírou intimních, přehnaně emocionálních a krajně subjektivních soudů o okolí. Místy je povaha vypravěčovy výpovědi natolik zaujatá vůči okolnímu světu a natolik emocionálně vypjatá, že je to až v přímém rozporu s textem, který se označuje za editorskou předmluvu. Navíc jako by právě tento „editorský“ text parodoval předpokládanou objektivitu textologických metod a postupů. Od samého počátku textu všech čtyř částí Bledého ohně je čtenář vystavován dvojznačnosti a nikdy si nemůže být jistý, z jaké perspektivy je vyprávěno, zda z poctivého a vážného záměru redaktora textu, anebo z pohledu nízkého a psychicky deformovaného malosvěta a mnohoznačnosti narážek nejrůznější povahy a úrovně. V editorské předmluvě se tak evidentně dostává do rozporu „vysoké“ (představa seriózního umění a umělecká hodnota poémy) a „nízké“ (pokleslý kontext sdělení Charlese Kinbotea).

\section{Poéma}

Za ústřední románovou kompoziční rovinu lze pokládat poému Bledý oheň, jež má 999 veršů, a čtenář je informován výlučně vypravěčem Charlesem Kinbotem, že autorem poémy je jistý John Francis Shade (5. 7. 1898 - 21. 7. 1959). Poéma je symetricky rozložena do čtyř písní, a přestože je její syžet jen velmi náznakový, lze v ní určit několik tematických celků.

Poéma začíná příznačným rozdvojeným obrazem jak poémy, tak komentáře, který lze považovat za klíčovou metaforu celého románu: pták, jenž se v plném letu roztř́ísí o vnější plochu okenního skla. Zrcadlový odraz nebe vytváří iluzi prodlouženého prostoru. Pták tak směřuje nikoliv do hlubiny nebeského nekonečna, ale k jisté smrti. Téma jevu a jeho zrcadlového odrazu či stínu bude posléze prolínat všemi kompozičními součástmi románu.

V případě složitých a málo srozumitelných souvislostí mezi pohybujícími se významovými rovinami a jejich neustálými proměnami, závislými na těkavé vypravěčské perspektivě, bude účelné popsat výchozí kompoziční rozložení jednotlivých rovin.

V první části básník z věkového odstupu znovuprožívá dětskou realitu, která už nemůže být nezatížená časem a zkušeností dospělosti. John Shade vnímá samotné obrazy vzpomínek jako projekci minulé reality na fotografický snímek současného vědomí. Jako by se realita od samého počátku dvojila v tvůrcově pohledu na objekty v minulosti a jejich současnou interpretaci. Vypravěč vidí dům, v němž žil, a pohrává si s barvami a otisky vlastní paměti, nebo naopak si otisky minulosti pohrávají s ním a jeho současností. Je nasvěcován film kdysi dávno promítnuté reality. Před básníkovým vědomím se vyjevují obrazy otce a matky, jejich práce, smrt a jeho vzpomínkou prolíná dětská modlitba za štěstí všech. Sám vypravěč se jmenuje John Shade, tedy stín. Zároveň se opakuje obraz roztř́ístěného ptáka o okenní sklo, které svým odrazem představuje iluzorní prostorovou hlubinu. Stále se vrací představa čehosi hraného, falešného, předstíraného, iluzorního, představa stínu, který nemá vlastní zdroj energie. Ve hře zrcadlového odrazu, stínu a světelného lomu je stále přítomen implicitní poukaz na něco opravdového, na skutečný 
zdroj energie, na nepředstíranou hodnotu a krásu. Tvưrčí stav a pozice Johna Shadea ve světě jsou vnímány jako zakletí, protože se není schopen orientovat v proměnách skutečného a neskutečného světa, původního obrazu či zdroje světla vưči jeho odrazu a stínu. Excentrická tetička Maud zemřela a zanechala po sobě rodovou stopu podivného pomatení smyslů a čehosi tajemného, nevysvětlitelného, zastřeného mlhou iracionality. „[...] v groteskni vizi divně zaplétala obyčejné a všedni předměty. " ${ }^{3} \mathrm{~V}$ okamžiku, kdy se dětské vědomí naplněné prožitky boha, času, smrti a př́rodního majestátu dostává na zápraží dospělého světa, nezvládne hrdina složitou změnu a prožívá kolaps. Vše proběhne náhle a dětský svět je oslněn zábleskem jiné reality. Přechodu z dětství v dospělost dominuje příslovce „náhle“. Na konci první písně hraje ústřední roli obraz hračky Smrti, která nad jeho dětstvím (autorem poémy) sice ztratila vládu, ale dále se stává stálou součástí jeho osobnosti.

Smrt a otázky spojené s posmrtným bytím procházejí také úvodem druhé písně, která dále pokračuje vyznáním lásky k ženě Sibyle a dceři Hazel. Kritickým okamžikem druhé písně je dceřina smrt. Manželé Sibyle a John Shade sledují bezduchou prázdnotu televizního filmu a jejich dcera Hazel časově souběžně prožívá krizi svého doposud podivně osamělého života. Poslední chvíle dcery Hazel jsou paralelně doprovázeny banálním přepínáním televizních programů s reklamami, jež defilují před očima rodičů. Druhá píseň končí obrazem, ve kterém slepý stín padá na dno jezera, v němž se dcera utopila. ${ }^{4}$

Třetí písni vévodí hoře nad ztrátou dětského života. Pokud se objevuje dětský svět, pak je spojován s hrou. Vztah ke světu a lidskému bytí je vyjádřen větou, že je jen těžko poznat, čím se „toto“ (tento život na tomto světě) liší od pekla. Shade v poémě uvádí, že po dceřině smrti už nic dál nebude a nechává se lhostejně unášet banálním plynutím všední reality. Srdeční záchvat Johna Shadea je uvozen větou, v níž si doktor pohrává s významem slova stín: „Doktore, byl jsem mrtvý! “Smál se. „Inu, ne zcela, Shade. Jen tak na půl stinu. " ${ }^{5}$ Prožitek smrti je vyjádřen obrazem bílé fontány. Ovšem Shadeovu domněnku podpoří uveřejněné poznámky jisté paní $Z$, která rovněž viděla bílou fontánu ve stavu klinické smrti. Paní Z napsala knihu The Land Beyond the Veil. John Shade projel tři sta mil, aby se setkal s duchovní spřízněnkyní posmrtného stavu, a z jejího rukopisu vysvitlo, že nešlo o duchovní znamení, ale o docela obyčejnou a bezvýznamnou tiskovou chybu. John Shade chce na vlastní oči uvidět mystické spříznění s tajemstvím posmrtného prostoru a uvidí pouze směšný a hloupý tiskový přehmat. Namísto rukopisného „hora-mountain“ je otištěno „fontána-fountain“. Nahodilost, která najednou změní celý duchovní svět Johna Shadea, je vyjádřena na první pohled bezvýznamnou tiskovou chybou: fontain-mountain. Jako by život věčný a jeho podstata byly postaveny na překlepu, na pitvorném šklebu tiskové chyby. Zároveň jsou různé jevy uvedeny do překvapivých souvislostí. Souvislost je vytvořena právě podivností a nahodilostí hry. A pokud smrtelník vnímá umělecké kouzlo hravých souvislostí, může se svým prožitkem těšit jako ten, který hru vytváří a ovládá jako

3 NABOKOV, Vladimir: Bledý oheñ. Praha: Paseka, 2011, s. 32.

4 O příčinách smrti dcery Hazel píše E. Antošina, která také věnuje pozornost parodii v Nabokovově textu. (ANTOŠINA, Elena: Koncept «potustoronne» kak objekt parodii i refleksii v romane V. V. Nabokova «Pale Fire» («Blednyj ogon’). Vestnik Tomskogo gosudarstvennogo universiteta, 2017, № 420, s. 5-15).

$5 \quad$ NABOKOV, Vladimir: Bledý oheň. Praha: Paseka, 2011, s. 55. 
demiurg hry. Je symptomatické, že Shade po návratu domů a Sibylině dotazu o výsledcích cesty říká, že cesta nebyla zbytečná. Pro Johna Shadea se tak otevřel prostor a cesta k nové naději. Byl na okamžik přítomen, či byl přímo součástí božské hry či božského žertu. Přikládáme anglický originál, v němž je smysl Nabokovových slov zcela průzračný a vysvítá z něho záměr podtrhnout význam hry a věčnosti založené na překlepu:
„Life Everlasting - based on a misprint!
I mused as I drove homeward: take the hint,
And stop investigating my abyss?
But all at once it dawned on me that this
Was the real point, the contrapuntal theme;
Just this: not text, but texture; not the dream
but topsy-turvical coincidence,
Not flimsy nonsense, but a web of sense.
Yes! It sufficed that I in life could find
Some kind of link-and-bobolink, some kind
Of correlated pattern in the game,
Plexed artistry, and something of the same
Pleasure in it as they who played it found. "6

Poslední čtvrtá píseň směřuje k úvaze o smyslu umění. Je v ní vysloven názor, že lidský život je komentářem k tmavé poémě bez konce. Stín je spojován s poémou a zároveň s lidským životem. A zde se nabízejí i výklady pro název poémy Bledý oheň (souvislosti se Shakespearem viz níže). Jednak může být tento název spojován s větou, v níž vypravěč odhaluje, že postihnout bytí nebo jeho malé části je možné pouze prostřednictvím umění. Bledý oheň je tak jen malým odleskem skutečného celku, který je možné vytušit prostřednictvím uměleckého obrazu a symbolu. Umění otevírá cestu k opravdovému bytí, jež není jen bledým ohněm, ale skutečným a plným svitem světelné záře.

Z druhé strany může být tento název chápán jako označení života, jevu, který potřebuje jistý zdroj opravdového svitu. Jako by Shadeova životní realita byla pouze stínem, bledým měsíčním svitem, který dává tušit, že za jeho odleskem existuje opravdový a na ničem nezávislý světelný zdroj, od kterého je bledý svit odvozen.

At̉ už jsou výklady názvu poémy jakékoliv ${ }^{7}$, je zcela jasné, že je zde čtenáři předkládána dvojí realita - šedivý, banální život rodiny manželů Shadeových, který začíná nadějně láskou a končí po ztrátě dítěte připodobněním života k peklu a smířením se s apatickou lhostejností a s životem, který nemá smysl. Ovšem zůstává naděje na skutečné bytí za hranicemi běžného poznání, k němuž mohou hrdinové pronikat jen prostřednictvím božské

6 NABOKOV, Viktor: Pale Fire. Penguin Classics, 2000, s. 53.

7 Název poémy a románu Bledý oheň se vztahuje ke Shakespearovu textu Timona Athénského (Timon of Athens) a př́slušným pasážím svitu Slunce a Měsíce. (The sun's a thief, and with his great attraction...). Srovnej např. LJUKSEMBURG, Aleksander - ILJJIN, Segej: Kommentarii. Blednoje plamja. In: NABOKOV, Vladimir: Sobranije sočinenij amerikanskogo perioda v pjati tomach. T. 3. Sankt-Peterburg: Simpozium, 1997, s. 663-664. 
hry uměleckých symbolů. Hrdinové se stávají součástí nadosobní hry a vystupují současně v roli jejího subjektu i objektu. Lze to chápat tak, že hrdinům je dáno, aby se podíleli na spoluvytváření hry, ale zároveň jsou jejími figurkami, se kterými je na šachovnici hráno a pohybováno z pozice vyšší moci. Jako by se tímto naplňovala úvodní metafora, ve které se pták střemhlav blíží k smrtonosné skleněné stěně. Na jedné straně pták let ovládá a je jeho pánem, na druhé straně je však odraz volného prostoru v okenním zrcadle natolik přesvědčivý, že je iluze prostoru zaměněna za realitu samu, a hrdina netuší, že před sebou nemá volný a ničím neomezený prostor, ale smrtonosnou sklovitou stěnu, o kterou se co nevidět roztříští. A od takto pojatého „bledého ohně“ či „stínu“ je odlišen svět pravého světla, zdroje vitality a smysluplného bytí. Prostřednictvím hloupého překlepu je indikována božská hra, jejímž prostřednictvím je možné nahlédnout do ničím neomezeného prostoru opravdového bytí a osvobozujícího plného světla.

Základními textovými východisky poémy Bledý oheň je rozdvojení umělecké reality, které nabývá mnoha tematických podob. Předně pak neustálé prolínání opravdové reality, pravého zdroje energie a světla a reality iluzorní, zdánlivé a odvozené, která pro hrdiny nabývá osudových poloh. Autor, který záměrně vytváří text a významy, se dobírá k poznání, že jde pouze o pseudovýznamy a pravé významy se tvoří na základě „zázraku slova“. Fantazijní kreace intelektu dává pouze impulz k živelné produkci významů bez ohledu na původní lidsky omezený autorský záměr a vše ostatní se děje následně a samo o sobě a vyvěrá z podstaty umění. Z toho plyne rovněž i téma bezprostředního života jednotlivých postav jako odlesku či stínu něčeho původního a podstatného. Vedle toho je zde obsaženo téma života jednotlivých postav povýšené na úroveň pravé božské hry a božské kreace. Tělesný a fyzický život je obklopen temnotou, stíny a pouhými odlesky opravdového zdroje světla a teprve prostřednictvím umění se lidské bytosti prodírají k prapůvodnímu zdroji životní energie a životní podstaty. Poéma Bledý oheň jako by stále připomínala, že za prvoplánovým textem je další text prapůvodních hodnot, osudových souvislostí a pravých podstat, které se postavám odhalují náhle a nečekaně a jejichž prostřednictvím se naše existence napojuje na něco nadosobního a podstatného. Z tohoto hlediska jako by poéma Bledý oheň navazovala na poezii ruského symbolismu, ve které se básník prostřednictvím umění-symbolu dobírá pravé podstaty jevů a symbol otevírá cestu k prapůvodním hodnotám. ${ }^{8}$

\section{Komentář}

Vedle poémy Bledý oheň spolutvoří Nabokovův text objemný komentář k poémě pořízený Charlesem Kinbotem. Problém je v tom, že je opět jen vytvářen dojem, že jde o ko-

8 V této souvislosti je možné nahlížet souvislost poetiky Bledého ohně a ruského symbolismu. D. Johnson je nejednou citován, když uvádí, že Nabokov ve svém díle zůstal věrný dvěma základním předpokladům ruského symbolismu, a to je: bezprostřední kontakt s tím, co se nachází za vnějším povrchem předmětů, a víra v umění, které má schopnost vyjevit pravdu o zákonitostech vyššího řádu, který řídí fenomenální svět. Srov. JOHNSON, D. B.: Belyj and Nabokov: A Comparative Overview. Russian literature, 1981, № 4, p. 379-402. V této souvislosti rovněž srovnej: BOJL PILO, Č.: Nabokov i russkij simvolizm (istorija problemy). Sankt-Peterburg: Izdatel'stvo Russkogo Christjanskogo gumanitarnogo instituta, 2001, s. 532-550. 
mentář. Ve skutečnosti komentář neodpovídá obsahově textu, ke kterému se primárně vztahuje. ${ }^{9}$ Text poémy Bledý oheñ, který je připisován autoru Johnu Shadeovi, významově neodpovídá komentáři redaktora Charlese Kinbotea. Komentář se pouze tváří jako komentář, ale ve skutečnosti není komentářem a s poémou se obsahově míjí a není adekvátní proklamovanému komentáři, za který je z nějakého důvodu Charlesem Kinbotem vydáván. Vše je založeno na tom, že autor komentáře Charles Kinbote se přidává k sérii výstředních nabokovských vypravěčských figur typu Humberta Humberta (Lolita) či Hermana Karloviče (Zoufalství). Jde o fantazéry, narcisy, manipulátory, blázny, přehlížené a ušlápnuté pleticháře, sebestředné lháře, podvodníky, kterým vévodí sebechvála, paranoiky a excentrické figury s nejrůznějšími poklesky, které rády vystavují na odiv svůj intelekt a mimořádné schopnosti. Těmto vykladačům událostí nelze důvěřovat a spoléhat se na hodnověrnost jejich sdělení ${ }^{10}$. V jejich výpovědi se často směšuje fantazie a realita, jisté okolnosti jsou zatajeny, jiné naopak překrouceny a jiné zase svévolně přidány. Fantazie se tak snoubí s halucinacemi, představami, iluzemi a smyšlenou realitou. Vše dohromady pak vytváří mnohoznačnou směsici různých a často si i odporujících výpovědí s různým stupněm důvěryhodnosti. ${ }^{11}$

Charles Kinbote se vydává za prŕítele z univerzity a souseda autora poémy Johna Shadea. Ale mohlo by to být i jinak: ve skutečnosti by autor komentáře mohl být ničím nevynikající ruský emigrant (V. Botkin), který nyní žije v Americe a přednáší na univerzitě. Z textu komentáře vyplývá, že by také mohlo jít o bezvýznamného homosexuála, paranoického pederasta, který se přes odpor manželky Johna Shadea Sibyly snaží být v neustálém a vtíravém kontaktu s rodinou autora poémy. Záměr autora komentáře může být také zcela prostý. Vedle ničím nezajímavého a banálního života ruského emigranta žije Kinbote sebestřednou až narcistní představou, že je ve skutečnosti exilovým králem neurčité severní země Zembly ${ }^{12}$, z níž se mu po revoluci podařilo tajně odejít. Král trpí stihomamem, jehož podstatou je člověk vyslaný z porevoluční Zembly, aby ho zabil. Tento člověk se jmenuje Jacob Gradus. Charlese Kinbotea zajímá John Shade také především proto, že má básnický talent a prostřednictvím jeho uměleckého slova by mohl být

9 O rozporu mezi textem poémy a údajným kritickým aparátem komentáře poznamenává V. Aleksandrov: „Поразительный разрыв между текстом поэмы и ее якобы критическим аппраратом представляет собой основную структурную проблему романа. “(ALEKSANDROV, Vladimir: Nabokov i potustoronnost. Sankt Peterburg: Aletejja, 1999, s. 225)

10 Toto chápání textu sdílí i V. Aleksandrov, když poznamenává: „[...] поучительно взглянуть на то, как разварачивается в романе система неопределенностей." (Ibidem, s. 225.)

11 Jde o nedivěrryhodného vypravěče, tak jak je tento termín používán v anglojazyčné literatuře (unreliable narrator). Jde o vypravěče, kterému nelze důvěřovat a nelze spoléhat na pravdivost jeho tvrzení. Tento vypravěč záměrně zatajuje pravdu, překrucuje informace o událostech, směšuje fantazii s realitou za účelem manipulovat se čtenáři a vnucovat jim představu o románové realitě, která není totožná s viděním jiných postav. Nedůvěryhodný vypravěč trpí v mnoha případech duševní chorobou a jeho nespolehlivá výpověd' se tak dostává z jeho pohledu na hranu záměrného a nezáměrného. Tento termín uvedl do literárněvědného povědomí Wayne C. Booth v r. 1961. Charles Kinbote je příkladem takového typu vypravěče, ale v této stati se problému z pohledu nevěrohodného vypravěče detailně nevěnujeme a směřujeme k jeho významovým důsledkům z hlediska ironie a parodie.

12 O komentáři srovnej: LJUKSEMBURG, Aleksander - IL'JIN, Segej: Kommentarii. Blednoje plamja. In: NABOKOV, Vladimir: Sobranije sočinenij amerikanskogo perioda v pjati tomach. T. 3. Sankt-Peterburg: Simpozium, 1997, s. 661. 
sdělen světu příběh exilového krále Karla II. Charles Kinbote tento příběh básníku Johnu Shadeovi údajně vyprávěl se záměrem, aby ho umělec Shade přebásnil do poémy. Umělecký jazyk by tímto zvěčnil Kinboteovu smyšlenou či nesmyšlenou vizi vlastního života. Charles Kinbote tvrdí, že po básníkově smrti údajně získal práva redigovat poému Bledý oheň. Po jejím přečtení však Kinbote zjistil, že poéma nevypráví heroický příběh exilového krále, který se snažil básníkovi svým vyprávěním předestřít a vnutit mu ho jako námět pro fabuli poémy, ale že obsahuje pouze vlastní příběh života Johna Shadea. Rovněž je mu jasné, že k napsání básně o králi a jeho zemi nemá talent, a proto mu nezbývá nic jiného než vepsat vlastním komentářem do poémy příběh o osudu krále Karla II. a o jeho vynuceném exilu. Sám Kinbote vidí v poémě Johna Shadea sice jisté hodnoty, ale nevidí kouzlo vlastního exilového př́iběhu, který básníkovi, podle jeho přesvědčení, dostatečně přesvědčivě popsal. Komentář proto doplní poému o zcela samostatný příběh, text, který se skladbou poémy Bledý oheň sice souvisí, ale ne tak, jak se autor komentáře snaží namluvit čtenáři. V komentáři Kinbote reaguje jako by na náznaky králova př́iběhu, které ale musí být dostatečně jasně rozvedeny, aby čtenář z poznámkového redakčního aparátu pochopil veškeré údajné souvislosti. Příběh vyprávěný Kinbotem má nejméně dvě roviny. První rovina obsahuje př́iběh krále Karla II., druhou rovinu tvoří cesta vraha Graduse za svou obětí. A aby byl výčet syžetových souvislostí úplný, Charles Kinbote má pronajatý dům od soudce, jenž odsoudil jistého vraha k dlouholetému trestu odnětí svobody. Maniakální trestanec se chce pomstít a záměna člověka, který dům pronajímá (soudce), s tím, kdo je pouhým nájemcem (Kinbote), je nasnadě.

Kompozice románu Bledý oheň v části komentáře nabízí nejméně tři významové roviny. První rovinou je realita, která se odvíjí prrímo před očima autora komentáře. Jedná se o evokaci světa amerického univerzitního prostředí, v němž se odehrává obyčejný život Charlese Kinbotea, tj. ruského porevolučního emigranta Botkina. Za jinou významovou rovinu lze pokládat vzpomínky údajného exilového krále Karla II., který se nyní skrývá v Americe nejspíš pod falešným jménem Charles Kinbote. Jedná se o vzpomínky na dětství, na tajný porevoluční útěk a na souvislosti spojené s údajnou královskou rodinou údajné severské země Zembly. Třetí příběh se rovněž odehrává ve vědomí Charlese Kinbotea. Gradus, politický vrah, najatý porevolučním totalitním režimem, údajně pronásleduje exilového krále, aby ho zavraždil a vykonal iracionální mstu zbytečné a nesmyslné politické zloby. At̉ už jsou jednotlivá témata smyšlena s určitým záměrem, nebo jsou plodem fantazie či vypravěčových přeludů, je třeba s nimi při výkladu románu právoplatně počítat, nebot jsou evidentně v románu významově přítomna.

Čtenář má tak před sebou editorskou předmluvu, která evidentně svým obsahem vybočuje z žánrového očekávání, které si běžně pod editorským vstupem lze představit. Jde o kombinaci různorodých prvků, parodických narážek a dvojznačností. Editorská předmluvu je tak vstupem nejrůznějších významových aspektů, které bude další románová skladba rozvíjet, a to především v podobě napětí mezi vysokým a nízkým, tradičním, předvídatelným, navyklými a očekávánými postupy a významy a na druhé straně významy a postupy novými, které předvídatelné postupy nabourávají a podvracejí. Čtenář očekává tradiční editorskou předmluvu, a zatím se setkává s textem, který toto očekávání nejenže nesplňuje, ale naopak se dostává do příkrého rozporu s předvídatelným žánrovým pů- 
dorysem. Nabízející se významy jsou tak oslabeny a nové významy zdůrazněny. Tyto postupy, které relativizují tradiční významy, je třeba chápat jako ozvláštnění ${ }^{13}$ uměleckého textu, ve kterém neočekávané estetické aspekty v uměleckém projevu překonávají tradiční automatismus opotřebovaných a zaběhnutých významů a postupů. Tradiční význam je vystaven mnohoznačnosti, která iniciuje neočekávané obsahové možnosti.

V následující části jsou očekávané významy v poémě Bledý oheň rovněž vystaveny dvojznačnosti, ovšem poněkud jiným způsobem než v úvodu. Jakýkoli význam je relativizován tím, že každý význam je chápán jako možný stín, odlesk, ozvěna skutečného smyslu, který je za hranicemi běžného poznání. Abychom se k pravému obsahu skutečně dobrali, je třeba využít uměleckého symbolu, který je schopen poukázat k hodnotám a významům na pozadí, k nimž se lze dobrat jen prostřednictvím umění a symbolu. Nabokovův text v této kompoziční části směřuje k intuitivnímu odhalování smyslu na pozadí očividných jevů a předmětů. Prostřednictvím umění je odkazováno na skutečnost mimo dosah empirického poznání. Intuitivní vidění významů na pozadí všední skutečnosti a odkrývání oblastí za hranicemi běžného poznání umožňují prostřednictvím umění nahlédnout do oblastí a životních dějů, které jsou před lidskými zraky obvykle skryty. Prostřednictvím umění je tak v Nabokovově textu navázán kontakt s věčností. Na první pohled jde o tiskovou chybu, překlep, hloupý žert (moutain/fountain), ale z druhé strany je navázán kontakt s něčím mimořádně vážným a podstatným. Světlo bledého ohně je tak pouhým odleskem prapůvodní energie a opravdového svitu. Odkazování k významům za hranicemi poznání se tak děje prostřednictvím symbolu. Tvůrcovy myšlenky se přetvářejí do uměleckých obrazů poémy, které neulpívají na jednom významu, ale mají schopnost se přetvářet do nových významových útvarů a překračovat hranice očekávaného. Rozpětí tradičního vjemu se tak neustále rozšiřuje o nové úhly. Díky umění se myšlenka neuzavírá, ale přetváří se v obraz a obsahově otevřený symbol, který se stále znovu promítá do nových souvislostí, perspektiv a významových možností.

V textu poémy je využito symbolu a jeho vlastnosti, díky které myšlenka vyjádřená symbolem zůstává navždy činná s otevřeným a neustále se rozvírajícím smyslovým potenciálem, s rozšiřujícím se obsahovým rozpětím, obrazným rozsahem a stálým významovým přebytkem. Myšlenka v symbolu přesahuje sama sebe, překračuje vlastní hranice a poukazuje na smyslovou oblast, která je s ním nedělitelně spojena, ale není s ním totožná.

Poéma Bledý oheň, tak jak to ostatně vyplývá i z jejího názvu, míří k pravému a neodvozenému svitu, pravému hodnotovému zdroji, k věčnosti a jejímu počátečnímu a prapůvodnímu hybateli. Ovšem poéma Bledý oheň má i další významová zpochybnění, a nejde pouze o dvojznačnost symbolického vztahu stínu a prapůvodní podoby věci, zdroje, a odvozeniny, která se vydává za zdroj.

13 ŠKLOVSKIJ, Viktor: Teorie prózy. Praha: Melantrich, 1933, s. 15-23. 


\section{Komentář: mnohočetnost hledisek}

Jak jsme již uvedli, Charles Kinbote je očividným příkladem nedưvěryhodného vypravě$\check{c} e^{14}$ a představuje širokou paletu vypravěčských masek (fantazér, manipulátor, podivín s evidentními psychickými problémy, přehlížený a ušlápnutý pletichář, sebestředný lhár̆, paranoik a excentrická figura s nejrůznějšími poklesky, která ráda vystavuje na odiv svůj intelekt a mimořádné schopnosti, narcis se zjevnou sebechválou). Každá z těchto vypravěčských podob vydává svědectví, která jsou si vzájemně místy až protichůdná, všemožně se různí, vzájemně překrývají a vytvářejí neúplný pohled na události v souladu s maskou, kterou právě sdílí. Charles Kinbote se ve všech svých proměnách a maskách vydává za zdroj informací a pravého výkladu uměleckého textu. Těmito prostředky je parodován žánr komentáře a do textu je prostřednictvím kombinace různorodých prvků (vypravěčské masky a s nimi spojené různé významové aspekty informování o událostech, systém narážek a dvojznačností) vnesena ironie.

Vycházíme z toho, že ironie a parodie mají schopnost vnášet do textu dvojznačnost. Dvojznačnosti je dosahováno tím, že jsou zpochybňovány tradiční významy, tradiční žánrové kódy a očekávané estetické postupy a jsou propojovány nesourodé prvky. Výsledkem ironie a parodie není pouze dvojznačnost, ale především na základě napětí a „dvojlomu“ mezi parodickým a ironickým „ano“ a „ne“ jde o rozšiřování předpokládaného obsahového rozpětí o nové významové oblasti a aspekty. Aktivace nových významů prostřednictvím ironie a parodie vnáší do textu nikoli jen dílčí významy, ale především novou estetiku, která je schopna pootočit románovou strukturu ke zcela nové estetické (žánrové) perspektivě. Ironie a parodie se tak stávají základem nových významů a živelně se tvořící nové románové reality. Stejně tak jako v dějinách literatury romantická ironie, tak i př́tomnost parodie a ironie v moderním románu je schopna generovat nečekané estetické úhly pohledu mezi póly „ano“ a „ne“.

Vedle dvou uvedených aspektů komentáře (téma odvozeniny stínu od původního zdroje a téma vystavení prostřednictvím ironie a parodie tradičního významu mnohočetným alternativám bez autoritativní nadřazené perspektivy), je třeba zdo̊raznit zásadní rozpor této části textu: komentář záměrně vnucuje poémě Johna Shadea významy, které evidentně neobsahuje. Je to případ, kdy na základě apriorního záměru interpretace v komentáři vykládá text v rozporu s jeho obsahem. Nebo, lépe řečeno, dodává mu smysly, které by měl podle předpokladů vykladače obsahovat.

Ovšem komentář se žánrově míjí s jeho očekávaným posláním: komentář není významově adekvátní k původnímu textu a neadekvátně na něho reaguje. Komentář kriticky nezpřesňuje text a neobsahuje poznámky, které by pomohly věcně poukázat na souvislosti ne zcela zřejmé ze samotného textu, ale vytváří významy, které nemají žádný nebo jen zcela mizivý vztah k původnímu textu. Tímto se vytváří metaforický text, který není pouze doplňujícím textem $\mathrm{k}$ původnímu textu poémy, ale samostatným a na původním textu (poémě) nezávislým útvarem. 
Komentář je ovšem čten $\mathrm{v}$ souvislosti s poémou Bledý oheň a komentář je čtenářem vnímán ve vztahu k původní poémě a původnímu textu. Původní významy poémy, které jsou vlivem komentáře rozšîřeny o další souvislosti, vstupují do spojení vzájemných představ a asociací. Původně izolované obrazy se tak dostávají do nezvyklého sousedství a tím i významových vztahů. Metafora tu pak vzniká dotýkáním, vzájemným pronikáním, prolínáním a prostupováním smyslových oblastí.

Jestliže první Kinboteovo téma navazuje na poému Bledý oheñ a snaží se vnutit okolí představu, že je to právě on, Charles Kinbote, který je pravým zdrojem umělecké a významové energie poémy, a ne pouze stínem a odleskem pravé hodnoty, pak druhé téma atakuje tradiční představu editorské předmluvy a komentáře a prostřednictvím mnohočetných významových podob vypravěče paroduje a ironizuje jeho vážnou podobu. Parodie a ironie jsou založeny na tom, že deklarovaná vážnost záměru je neustále podvracena formou, jakou je vše realizováno. Toto téma je společné pro všechny tři Kinboteovy vstupy: editorská předmluva, komentář a věcný rejstř́ík (viz např. Kinboteův autoportrét). Podstatou třetího tématu je násilné vkládání dodatečných významů do poémy prostřednictvím komentáře Charlese Kinbotea. Opět jde svým způsobem o parodii stínového „spolutvůrce“ či „pseudotvůrce“ na pozadí opravdového tvůrčího zdroje a počátku.

Síla spolutvůrců a zároveň jeho ironie je odvozena od poslední věty editorské předmluvy (,[...] ale at’ už je tomu jakkoli, posledni slovo má autor komentárée), ze které vyplývá, že se text koneckonců dostává do rukou neomezených vládců - editorů, kteří si s ním mohou neomezeně dělat a dělají, co uznají za vhodné. Jde o téma svévolné interpretace, která přebírá moc nad textem a předává umělecký text do rukou pseudovykladačů, kteří ho připodobňují $\mathrm{k}$ obrazu svému. $\mathrm{V}$ př́ípadě komentáře Charlese Kinbotea se poéma $\mathrm{v}$ dialogu ${ }^{15} \mathrm{~s}$ násilným komentářem ocitá ve dvojznačném parodickém a ironickém dvojlomu mezi „ano" a „ne“.

Důsledkem takovéto podvojné osnovy ediční poznámky, poémy, komentáře a rejstř́íku je hledání významů, které vznikají prolínáním vzájemně prostupujících textů: jeden, který je napsán, a druhý, který je čtenářem (prostřednictvím parodie a ironie) hledán, a tím jsou i hledány a vytvářeny nové významy, které by nemohly vzniknout, kdyby románový text ve všech jeho rovinách a kompoziční souhře nebyl založen na koncepci stále přítomného napětí parodických a ironických pólů. Zde máme na mysli text, pro který je zásadní ambivalence současného „ano" i „ne“.

$\mathrm{Z}$ toho plyne rovněž i téma bezprostředního života jednotlivých postav jako odlesku či stínu něčeho původního a podstatného. Tělesný a fyzický život je obklopen temnotou, stíny a pouhými odlesky opravdového zdroje světla a teprve prostřednictvím umění se lidské bytosti prodírají k prapůvodnímu zdroji životní energie a existenciálnímu základu. Poéma Bledý oheñ jako by stále připomínala, že za prvoplánovým textem je další hledaný text prapůvodních hodnot, osudových souvislostí a pravých podstat, které se postavám

15 Jak připomíná V. E. Aleksandrov, je třeba mít na žreteli: “Совершенно очевидно, что огромное значение для понимания романа имеет то обстоятельство, что при всем несомненном своеволии Кинбота в истолкова нии текста поэмы остаются между нею и его рассказом тонкие пераклички, многие из которых, между прочим, он и сам не замечает. (Ibidem, s. 241.) 
odhalují náhle a nečekaně a jejichž prostřednictvím se naše existence napojuje na něco nadosobního a zásadního.

Prostřednictvím všudypřítomné ironické a parodické ambivalence současně platného „ano“ i „ne“ ve všech částech románu Bledý oheň, a tím i nově vzniklých významových souvislostí, je navozena představa tragikomické osudové hry, do jejíhož koloběhu se postavy dostávají, nemohou se z ní vymanit ani se dobrat jejích pravidel.

V tomto kontextu veškeré lidské snahy (komentář dr. Kinbotea) o vytvoření si vlastního světa a vlastních pravidel hry působí jen jako směšná parodie lidského úsilí o překonání lidské gravitace.

\section{Literatura}

BOOTH, Wayne C.: The Rhetoric of Fiction. The University of Chicago Press, 1961.

NABOKOV, Vladimir: Pale Fire. Penguin Classics, 2000.

NABOKOV, Vladimir: Sobranije sočinenij amerikanskogo perioda v pjati tomach. T. 3. Sankt-Peterburg:

Simpozium, 1997.

NABOKOV, Vladimir: Blednoje plamja. Sverdlovsk: Biblioteka Čeloveka «91», 1991.

ALEKSANDROV, Vladimir: Nabokov i potustoronnost'. Sankt Peterburg: Aletejja, 1999.

ANTOŠINA, Elena: Koncept «potustoronne» kak objekt parodii $i$ refleksii v romane V. V. Nabokova «Pale

Fire» («Blednyj ogon’). Vestnik Tomskogo gosudarstvennogo universiteta. 2017. № 420, s. 5-15.

BOJL PILO, C̆.: Nabokov $i$ russkij simvolizm (istorija problemy). Sankt-Peterburg: Izdatel'stvo Russkogo Christjanskogo gumanitarnogo instituta, 2001, s. 532-550.

JOHNSON, D. B.: Belyj and Nabokov: A Comparative Overview. Russian literature, 1981, № 4, p. 379-402.

LJUKSEMBURG, Aleksander - IL'JIN, Segej: Kommentarii. Blednoje plamja. In: NABOKOV, Vladimir: Sobranije sočinenij amerikanskogo perioda v pjati tomach. T. 3. Sankt-Peterburg: Simpozium, 1997.

ŠKLOVSKIJ, Viktor: Teorie prózy. Praha: Melantrich, 1933.

prof. PhDr. Zdeněk Pechal, CSc.

Katedra slavistiky

Filozofická fakulta, Univerzita Palackého v Olomouci

Křřžkovského 512/10, 77180 Olomouc, Česká republika

zdenek.pechal@upol.cz 